\title{
Pemanfaatan Organisasi Lokal untuk Mengentaskan Kemiskinan
}

\author{
Oleh : Djamaludin Ancok
}

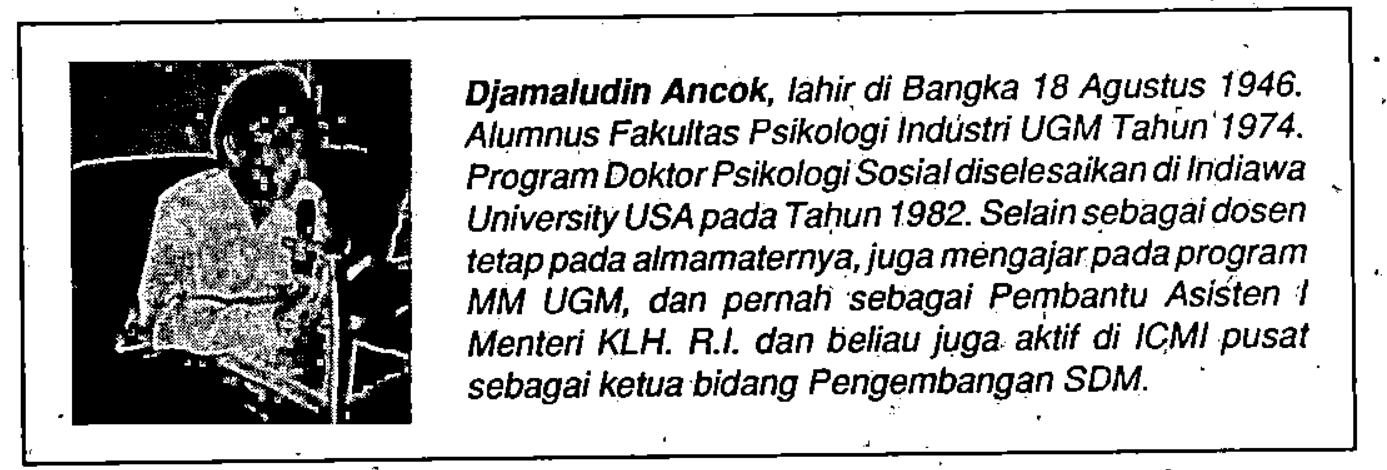

\section{Masalah Kemiskinan}

Tiga pendekatan ilmiah yang cukup populer dalam memahami masalah kemiskinan ialah"pendekatan kultural' dan 'pendekatan situasional'.

\section{Pendekatan Kultural}

Tokoh utama yang menggunakan pendekatan kultural ialah Oscar Lewis (1966). Dengan konsep 'cultural poverty' Lewis berpendapat bahwa kemiskinan adalah suatu budaya yang terjadi karena penderitaan ekonomi (economic deprivation) yang berlangsung lama. Berdasarkan penelitian pada beberapa kebudayaan kelompok etnik, Lewis menemukan bahwa kemiskinan adalah salah satu sub-kultur masyarakatyangmempunyai kesamaan ciri antar etnik satu dengan etnik yang lain. A'kardari timbulnya budaya miskin tersebut,' menurut pendapat Lewis, adalah keadaan masyarakat yảng mempunyai ciri-ciri berikut ini: 's

1. Sistem perekonomian yang terlalu berorientasi pada pencári keuntungan.

2. Tingginya angka pengangguran dan angka 'under employment' bagi golongan yang tidak punya keahlian (unskilled labor).

3. Rendahnya upah/gaji yang diperoleh para pekerja.

4. Tidak adanya organisasi sosial, politik dan ekonomi bagi kaum miskin, baik yang didirikan oleh Pemerintah maupun oleh swadaya masyarakat (Non-Governmental Organization).

5. Hadimya sistem kekeluargaan yang bilateral menggantikan sistem yang unilateral.

6. Hadirnya kelas masyarakat yang dominan, yang menekankan pada penumpukan harta dan kekayaan, kesempatan untuk terus meningkat dalam' status (upward mobility). 
Anggota kelas masyarakat ini beranggapan bahwa kemiskinan disebabkan oleh karena sifat yang lemah dan inferior.

Menurut Lewis (1966) budaya kemiskinan adalah suatu cara yang dipakai oleh orang miskin untuk beradaptași dan berekasi terhadap posisi mereka yang marginal dalam masyarakat yang memiliki kelas-kelas dan bersifat individualistik dan kapitalistik. Budaya kemiskinan adalah 'desain kehidupan' bagi orang miskin yang berisikan pemecahan bagi problemaproblema hidup mereka, yang diturunkan dari satu generasi ke generasi selanjutnya.

Dalam menggambarkan cara hidup orang yang berada dalam budaya kemiskinan Lewis memformulasikan serangkaian sifat-sifat (traits) ekonomi, sosial dan psikologi yang saling berkaitan satu dengan yang lainnya. Ciri pokok dari orang-orang yang hidup dalam budaya kemiskinan adalah 'kurangnya partisipasi yang efektif dan integratif dalam institusiinstitusi penting yang ada dalam masyarakat. Hal ini disebabkan antara lain olehkarena merekabanyak yang buta huruf dan berpendidikan rendah serta kekurangan uang. Kehidupan mereka yang serba kekurangan, kondisi tempat tinggal yang sańgat menyedịkan, kesumpekan tempat tinggal, kekurangan makanan dan pakaian telah mempengaruhi aspek psikologik mereka. Kehidupan seksual yang agak bebas, penelantaran anak, kưrangnya fasilitas pendidikan, tidak memungkinkan mereka untuk mendidik anaknya kearah pertumbuhan yang baik. Orang-orang yang dibesarkan dalam budaya kemiskinan mempunyai ciri-ciri kepribadian antaralain: merasa diri mereka tidak berguna, penuh dengan keputus-asa-an, merasa inferior, sangat dependen pada orang lain. Mereka juga tidak memiliki kepribadian yang kuat (ego-strength), kurang bisamengontrol diri, mudah impulsif, dan sangat berorientasi pada masa kini tanpa memikirkan masa depan. Sifat-sifat ini menyebabkan mereka sulituntuk membuat perencanaan bagi masa depan mereka.

Sifat-sifat yang merupakan ciri orang-orang dari budaya kemiskinan tersebut, menurut pendapat Lewis, dapat tumbuh dalam kelompok orang miskin yang hidup di negara manapun. Sifat-sifat tersebut dapat digunakan sebagai cara untuk beradaptasi terhadap tekanan kehidupan, tetapi sifat tersebut juga merupakan belenggu yang menyulitkan mereka untuk lepas dari tekanan kehidupan tersebut.

Untuk menghilangkan budaya kemiskinan tersebut, Lewis menyarankan agar orang-orang miskin bersatu dalam suatu organisasi. Lewis (1966) menulis dalam buku The Study of Slum Culture -Backgrounds for La Vida seperti berikut: Any movement -- be it religious, pacifist. or revolutionary - that organizes and gives hope to the poor and effectively promotes solidarity and a sense of identification with larger groups destroys the psychological and social core of the culture of proverty. (Setiap gerakan -- baik itu gerakan bersifat religius, pasifis, ataupun revolusioner yang mengorgänisasikan dan memberikan harapan bagi si miskin dan secara efektif mempromosikan solidaritas dan perasaan identitas yang sama dengan kelompok masyarakat yang lebih luas, akan dapat menghancuíkan sifat-sifat utama yang merupakan ciri orang-orang dari budaya kemiskinan). 


\section{Pendekatan Situasional}

Charles A. Valentine (1968) menggunakan asumsi yang berbeda dari asumsi Lewis, mengatakan bahwa ciri-ciri sub-kultur orang miskin seperti yang digambarkan 'oleh Lewis bukanlah 'suatu hasil kebudayaan yang turun temurun. Ciriciri itu timbul oleh karena situasi yang menekan. Bilamana situasi yang menekan itu hilang, ciri-ciri tersebut akan hilang dengan sendirinya. Situasi yang menekan tersebut timbul oleh karena struktur total dari sistem sosial yang ada di dalam suatu masyarakat. Tentang hal ini Valentine menulis dalam buku Culture and Proverty: Critique and Counter Proposals:

Lack of work, lack of income, and the rest pose conditions to which the poor must adapt through whatever sociocultural resources they control. That is, these conditions are phenomena of the environtment in which the lower class lives, determined not so much by behaviors and values of the poor as by the structure of the total social system.

Menurut pendapat. Valentine untuk merubah keadaan orang-orang miskin ke arah yang lẹbih baik harus diadakan perubahan yang simultan. dalam tiga hal: Pertama, penambahan 'resources' (kesempatan kerja, pendidikan, ddl) bagi orang miskin. Kedua, perubahan struktur sosial masyarakat; dan ketiga, perubahanperubahan di dalam sub-kultur masyarakat orang miskin tersebut. Sumber perubahan yang paling mungkin menurut Valentine adalah 'gerakan-gerakan sosial untuk 'menghidupkan kembali keyakinan dari orang miskin!. Gerakan ini haris berasal dari dalam kelompok orang miskin tersebut. Bila telah timbul kéyakinan diri tersebut maka hambatan-hambatan kultural yang merupakan ciri masyarakat miskin akan terkikis.

\section{Pendekatan Interaksional}

Ahli lain yang mengajukan pendapatnya tentang kehidupan orang miskin adalah Herbert J. Gańs (1968). Menurut Gans perilaku dan ciri-ciri yang ditampilkan para kaum miskin adalah merupakan hasil interaksi antara faktor kebudayaan yang sudah tertanam di dalam diri orang "miskin dan faktor situasi yang menekan. Gans tidak sependapat dengan Lewis yang mengatakan bahwa orang miskin disemua negara mempunyai ciriciri yang sama. Gans berpendapat bahwa orang-orang miskin bersifat heterogen. Sebagian orang miskin.menjadi miskin karena warisan generassi sebelumnya, sedangkan sebagian orañg miskin lainnya hanya miskin secara periodik. Sebagian orang miskin bertambah miskin (downwardlymobile) sedangkan sebagiannya lagi bertambah baik kehidupannya (upwardly mobile). Sebagian darimereka berorientasi ke atas dan melihat adanya kesempatan untuk maju, sedangkan sebagian lainnya tidak berorientasi demikian dan tidak menggunakan kesempatan yang tersedia untuk meningkatkan kualitas hidup mereka. Gansmenolak anggapan bahwa kebudayaan itu bersifat 'holistik' yang elemennya hánya dapat berubah bilamana semua sisteni budaya tersebut berubah.

Menurut Gans pemecahan terakhir masalah kemiskinan terletak pada usaha untuk mengetahui faktor-faklor yang menghambat orang miskin untuk menggunakan kesempatan yang tersedia, dan usaha untuk memberikan keyakinan 
diri pada si miskin untuk menggunakan kesempatan yang tersedia walaupun kesempatan yang tersedia tersebut mungkin bertentangan dengan nilai-nilai kebudayaan yang dia anut saat itu. Untuk menyediakan kesempatan tersebut diperlukan suatu pemahaman tentang perubahan yang diperlukan dalam sistem ekonomi, struktur kekuasaan, dan norma-norma serta aspirasi kelompok orang kaya yang ikut memungkinkan timbulnyakelompok orang miskin.

Debat klasik mengenai penyebab kemiskinan seperti yang diungkapkan oleh ketiga pendekatan diatas tidak akan habishabisnya. Masing-masing mempunyai kelemahan dan kenggulannya. Untuk pengembangan konsep pengentasan kemiskinan sebaiknya semua aspek di atas diperhatikan dalam pengembangan program.

\section{Pemanfaatan Organisasi Lokal untuk Mengentaskan Kemiskinan}

Berdasarkan beberapa pemikiran yang dilontarkan oleh ketiga kelompok pendekatan kemiskinan tersebut di atas, penulis berpendapat bahwa peluang untuk sukses dalam mengentaskan kemiskinan akan lebih besar bila kaum miskin diberi peluang yang lebih besar untuk mengurus dirinya sendiri, mempengaruhi keputusan, dan berpartisipasi dalam kegiatan yang mempengaruhi kemampuan ekonomi dan kesejehteraan hidupmereka. Peranan pihak pemerintah sejauh mungkin dibatasi pada upaya merealisasikan kehendak masyarakat,penyediaan dan dan prasarana.

Beberapa pakar berpendapat bahwa keterlibatan masyarakat dalam mengurusi diri mereka akan menjadi penopang keberhasilan pengentasan kemiskinan karena akan menumbuhkan perasaan bangga atas kemampuan diri sendiri (lihat konsep TQC di dalam upaya peningkatan produktivitas dalam Feigenbaum, 1991, Konsep manajemen partisipatif, dalan Robbin, 1993). Tentu saja pemberian peluang kepada masyarakat miskin untuk mengurusi dirinya sendiri bukan satusatunya jalan untuk mengentaskan kemiskinan mereka. Ada beberapahal lain yang harus dilakukan oleh Pemerintah bersama masyarakat untuk menopang kegiatan pengembangan kaum miskin ini. Beberapa hal berikut ini diperlukan kehadirannya guna menopang kesuksesan pengentasan kemiskinan (lihat Esman \& Uphoff, 1984).

1. Inventasi pelayanan masyarakat dalam bidang infrastruktur. fisik dan infrastruktursosial; seperti jalan, sumber air bersih, irigasi, sekolah dan klinik kesehatan. Jalan-jalan hendaknya merupakan jalan yang dihubungkan ke kota yang menyediakan berbagai pelayanan. Sekolah, klinik, sumber air bersih dan irigasi hendaknya'dipelihara oleh pemerintah dan masyarakat secara bersama-sama, baik dari segi pendanaan maupun kegiatannya. Tujuannya agar masyarakat merasa ikut memiliki. Walaupun masyarakat ikut menyumbang dana dan tenaga namun: sumber dana utama adalah pemerintah.

2. Kebijakan pemerintah yang menguntungkan masyarakat miskin, misalnya dalam hal harga produk. pertanian yang memadai, insentif bagi petani miskin dan pengusaha non-farm yang miskin, serta kebijakan pembangunan yang menumbuhkan 
kesempatan kerja.

3. Teknologi. Penyediaan teknologi bagi simiskin masih dalam' kemampuan mereka untuk membayar kembali biaya teknologi (misalnya traktor sederhana dengan harga murah), dan fasilitas teknologi untuk' kegiatan non-farm (seperti tungku hemat energi untuk memasak krupuk, alat-alat pertukangan untuk pembuatan produk kerajinan dil).

4. Kelembagaan yang efektif yang mampu menumbuhkan sinergisme dalam kerja. Kelembagaan yang ${ }^{+}$memiliki keterpaduan kerja ini meliputi:

a) Jaringan kerja instansi pemerintah yang memberikan pelayanankepada masyarakat guna meningkatkan produktivitas kerja dan kualitas hidup. Jaringan kerja ini meliputi bartuan peningkatan próduktivitas seperti, lembaga risét pertanian, lembaga pemberi kredit, lembaga pengembangan pemasaran, lembaga konsultasi usaha kecil, lembaga pengelola irigasi, dll. Di samping itu jaringan kerja instansi untuk peningkatan pendidikan, kesehatan, dan keluarga berencana perlu juga dikembàngkan.

b) Jaringan kerjapengusaha pemerintah (BUMN/BUMD), koperasi, pengusaha swasta dan lembaga swadaya masyarakat yang: ikut membantu pengembangan kemampuan mașyarakat dalam hal pemasaran produk pertanian/non pertanian, dan pembinaan manajemen usaha.

c) Lembaga lokal kemasyarakatan seperti paguyuban petani, lumbung paceklik, kelompok pengajian, kelompok kesenian, kelompok apsari; PKK, dll:

Kelembagaan di atas saling membantu bukannya saling menjegal agar supaya kesuksesan program dapat diraih.

Kesuksesan program pengentasan kemiskinan ditentukan oleh sejauhmana pemerintah melibatkan secara aktif organisasi lokal disamping pemaksimalkan sinergisme antar lembaga pemerintah, LSM, lembaga swasta yang secara bersamasama diarahkan untuk menunjang pelaksanaan program.

Selain itu pemerintah perlu mengurangi secara gradual keterlibatan Pemerintah di dalam penentuan jenis kebijaksanaan yang harus diambil. Terlalu banyak campur tangan pemeriniah akan menbuat perasaan ketergantungan pada pemerihtah, selain itu juga tidak menumbuhkan kemąndirian masyarakat di dalam mengelola kepentingan mereka sendiri. Sama halnya dengan peranan pihak pengusaha baik BUMN/BUMD dan pengusaha swasta secara pelan-pelan mereka juga terus mengurangi keterlibatan mereka bilamana masyarakat dirasakan. sudah cukup mandiri di dalam mengelola kegiatan bisnis mereka sendiri. Tujuan akhir dari semua pengurangan keterlibatan ini àdalah untuk menumbuhkan kemandirian, kemampuan masyarakat, serta perasaan bangga atas prestasi mereka sendiri. Dari sini diharapkan akan hilang segala penghambal kemajuan mereka termasuk budaya kemiskinan yang dilontarkan oleh OscarLewis yang telah dibicarakan di atas.

Secara skematik pergeseran peran tersebut berubah dari perubahan pendekatan dari Pendekatan-I, ke arah Pendekatan-III seperti yang diringkas dalamTabel-1. 
Tabel 1. Alternatif Pendekatan Pengentasan Kemsikinan

\begin{tabular}{|c|c|c|c|}
\hline & 1 & & \\
\hline Mekanisme Utama & Struktur Birokrasi & Kebutuhan Pasar & Keterikatan Sựkarela \\
\hline Pembuat Keputusan & Administrator & Pengusaha, konsumen & Pimpinan dan anggota \\
\hline Dasar tindakan & Peraturan & Harga Pasar & Kesepakatan \\
\hline Kriteria Keputusan & Kebijakan Pemrth & Efisiensi & Kepentingan anggota \\
\hline Sanksi & Kekuasaan Pemirth & Kerugian uang & Tekanan sosial . \\
\hline Model operasi & Top-down & individualistik & Bottom-up \\
\hline
\end{tabular}

\section{Penutup}

Apa yang ditulis dalam makalah ini adalah sekelumit formulasi, untuk mengentaśkan kemiskinan. Tentu saja apaapa yang dikemukakan di atas sudah kita ketahui semuanya. Problem pokoknya adalah bagaimana menjalankan mekanisme di atas. Sạlah satu cara untuk mengaktifkan koordinasi tersebut adalah dengan membuat tolok ukur kemajuan instansi Pemerintah dari segi kemampuan dalam menjalankan mekanisme di atas sehingga masyarakat betul-betul mandiri.

$\therefore$ 